\title{
Indonesian Pencak Silat Athletes Management
}

\author{
Lesmana ${ }^{1}$, Tatang Muhtar ${ }^{2}$, Nurlan Kusmaedi ${ }^{3}$, Adli Hakama ${ }^{4}$ \\ \{Ikalesmana1612@gmail.com ${ }^{1}$, tatangmuhtar@upi.edu², \\ nurlankusmaedi11@gmail.com $\left.{ }^{3}\right\}$ \\ Indonesia University of Education, Bandung, Indonesia ${ }^{1234}$
}

\begin{abstract}
Researches concerning the implementation of coaching management and how the relationship of management to achievement were needed. This research uses a descriptive method with a quantitative approach. The sample used in this study was the Pencak Silat national team at the 2017 Sea Games 2017 and the 2018 Asian Games, totaling 30 athletes. The instrument used in this research was a questionnaire based on management theory from Bucher and Krotee. The results showed the team management with an overall average score of 173.13 entered in good category. The most prominent in the team management was controlling with a score of 132.43 , followed by organizing, staffing with each an average score of 128.57 and 128.22 . There was a significant and positive relationship between management and team achievements. Overall management contributed $66.3 \%$ in determining the success of team achievements. Whereas based on the indicators, the biggest contributors were staffing indicators $(71.2 \%)$.
\end{abstract}

Keywords: management, pencak silat, achievement

\section{Introduction}

Sports is a form of planned and structured physical activity that involves bodily movements and intended to improve physical fitness [1]. Sport is a part of daily basic needs because it can increase person endurance [2]. In principle, the development of sports rests on three orientations, namely sports as recreation, sports as health and sports as achievements [3]. Indonesian Pencak Silat Achievement experienced ups and downs, in 2016 at the world championship held in Bali, Indonesia as the host managed to become the overall champion after winning 12 gold medals. But unfortunately the glorious achievement dived sharply when the 2017 Sea Games event in Kuala Lumpur, Malaysia. The Indonesian Pencak Silat Team was only able to bring home two gold, four silver and nine bronze. These results made the Indonesian Pencak Silat team failed to meet the target of 3 gold medals in the Southeast Asia sport multi event. Many factors have led to the drastic decline in the Indonesian Pencak Silat achievements in the multi event sport in Southeast Asia. From the study and analysis of the Coaching Team, the failure was largely influenced by non-technical factors.

In law no. 3 Year 2005 on National Sports System [4] explained that national sports coaching is inseparable from the role of education. While article 27 paragraph 4 states that "the fostering and development of sports achievements are carried out by 
empowering sports associations, fostering national and regional sports coaching and organizing competitions in stages and in a sustainable manner". According to [25] the system of fostering sports achievement cannot be ignored that to achieve maximum results from a performance it is necessary to have a National Sports Development System that includes: ten policy pillars, including: 1) financial support, 2) sports institutions consisting from the structure and content of integrated sports policies, 3) marketing (participation), 4) fostering achievement, (promotion and identification of talent), 5) elite or top achievement (reward and sense of secure), 6) training facilities, 7) procurement and development of trainers, 8) national competition, 9) research, and 10) environment, media and sponsors.

The intensive and competitive coaching process is very tight competition, when it comes out as a winner it will become an athlete with extraordinary achievements and can be said to be an elite athlete [5]. In the laws of the Republic of Indonesia law number 3 of 2005 concerning the National Sports System [4], Achievement Sports are sports that foster and develop sportsman in a planned, tiered, and sustainable manner through competitions to achieve achievements with the support of sports science and technology. Achievement in sports is a complex matter, because it involves many factors, including internal factors such as physical and mental athletes, as well as external factors such as coaches, organizations, infrastructure and the environment [6]. Internal factors actually came from the quality of the athlete itself, where qualified athletes mean that in addition to having an innate talent in accordance with the demands of the sport, they also have good motivation and attitude so that they are ready to be developed to reach peak performance [7]. In the process of fostering sports achievements, synergy is needed from all elements [8]. One of the element is an experienced and educated trainer. Educated trainers are trainers who master training theories and understand the problems related to coaching [9] [10]. As a result of a coaching process carried out by educated trainers, the opportunity to achieve is far greater than the coaching process carried out by trainers who do not have the fundamentals of coaching. Good training can guarantee the implementation of the training process to achieve the desired performance [8]. [11] states "The importance of coaching is self-evident. Coaches are responsible for developing athletes' mental, physical, technical, and tactical abilities, and in addition to all of these responsibilities, they are also expected to win". The meaning of the statement is the importance of coaching that is clear. The coach is responsible for developing the athlete's mental, physical, technical, and tactical abilities, and for the purpose of all these responsibilities, the ultimate goal is to win.

From a variety of management theories the management functions are inventoried as planning, organizing, leadership, controlling and staffing [12]. Theoretically it can be said that sports performance organizations that can perform management functions properly can be expected to produce good achievements [13]. As said by [26] "management is the process by which key leadership personnel, so that the organization functions efficiently and effectively in achieving organizational goals." This shows that the role of organizational management in implementing its programs has the potential to produce achievements. Based on the effectiveness structure and organizational management practices reflected in the success or lack of the team. According to experts there are several functions, some of which according to [27] that "the nine functions of sport management are planning, organizing, staff- 
ing, directing, motivating, leading, controlling, monitoring, and evaluating". In this study it is concluded that management is an art of science and process in carrying out organizational activities such as planning, organizing, directing and controlling by utilizing other organizational resources to achieve the stated goals.

\section{Method}

The method used in this study is a descriptive method with a quantitative approach to the research design described in the following table:

Table 1. Research Design

\begin{tabular}{lc}
\hline Management (planning, organizing, leadership, controlling, staffing ) & Achievement \\
\hline $\mathrm{X}$ & $\mathrm{Y}$ \\
$\mathrm{X}$ 1 : Sea Games 2017 pencak silat national team management & \\
$\mathrm{X}$ 2 : Asian Games 2018 pencak silat national team management & \\
$\mathrm{X}$ & $\mathrm{Y}$ \\
\hline
\end{tabular}

The respondents involved were the Indonesian Pencak Silat contingent at the Sea Games 2017 \& Asian Games 2018 with a total of 30 people who joined the team as athletes, coaches and management. In this study using a management questionnaire instrument according to book Management of Physical Education and Sport by [26] there were 40 statements using a 5 rating scale. With data analysis using SPSS Statistical Product and Service Solution (SPSS) for Windows version 20.0 with the steps of the statistical assumption test in the form of normality test then continued with the hypothesis test. In this study, researchers set the following data collection procedures:

1) Preparation Phase, consisting of the following steps:

(a) Submission title on lecturers, preparation of proposals and proposals seminar

(b) Trial questionnaire to different samples

(c) Submission of a research permit to and from the SPS UPI Sport Education department, then submitted to PB IPSI

2) Implementation Phase, consisting of steps of activities;

(a) Provision of questionnaires to each sample

(b) Interview by one athlete

3) Reporting Phase consists of steps of activities;

(a) Carry out processing and analysis of data that has been collected, using SPSS

(b) Making interpretations, making conclusions and recommendations of research results

(c) Prepare a complete thesis text. 


\section{Results and Discussion}

Here are the results of the description of the data obtained by researchers at the time of conducting research.

Table 2. Overall Management Data Description

\begin{tabular}{rccccc}
\hline $\mathbf{N}$ & Min & Max & Average & SD & Amount \\
\hline 30 & 156 & 187 & 173,13 & 6.46 & 5,194 \\
\hline
\end{tabular}

Table 2 shows the overall management score acquisition data. The data was obtained from 30 Respondents of Indonesian Pencak Silat National Team members at the Sea Games 2017 and Asian Games 2018 events. Overall the total score was 5,194, an average of 173,13 , a standard deviation of 6.46 with a minimum score of 156 and a maximum score of 187 Data as a whole has not been able to provide a clear picture. Therefore, to provide a further picture, the researcher makes a score criterion using the norm reference assessment guideline (PAN). Based on the guideline of these criteria, the results of the criteria can be seen in Table 3

Table 3. Management Scores Criteria for Indonesian Pencak Silat National Team

\begin{tabular}{cllc}
\hline No & \multicolumn{1}{c}{ Vulnerable Score } & & Criteria \\
\hline 1 & $183+$ & A & Very good \\
2 & $173-182$ & B & Good \\
3 & $163-172$ & $\mathrm{C}$ & Enough \\
4 & $158-162$ & $\mathrm{D}$ & Less \\
5 & 157 and below & E & Very less \\
\hline
\end{tabular}

Based on the management score criteria in Table 4.2, researchers can provide criteria on the management research data of the Indonesian Pencak Silat National Team. Referring to the overall data summary that has been shown in Table 4.1 earlier, shows the average, minimum and maximum scores. With reference to the score criteria that have been designed, the overall average score of 173.13 is included in the criteria of Good. While the minimum score with a score of 156 falls into the Very Poor criteria, and the highest score with a score of 187 falls into the Very Good criteria.

Then in table 4 the researchers poured national team management data based on assessment indicators. 
Table 3. National Team Management Data Based on Assessment Indicators

\begin{tabular}{cccccc}
\hline Indicator & $\mathbf{A}$ & $\mathbf{B}$ & $\mathbf{C}$ & $\mathbf{D}$ & $\mathbf{E}$ \\
\hline Amount & 131.7 & 128.57 & 128.22 & 130.08 & 132.43 \\
& 3 & & & & \\
Average & 4.39 & 4.28 & 4.27 & 4.33 & 4.41 \\
Standard & 0.38 & 0.23 & .28 & .22 & 0.25 \\
Deviation & & & & & \\
Minimum & 3.71 & 3.88 & 3.50 & 4 & 3.86 \\
Maximum & 5 & 4.75 & 4.88 & 4.75 & 5 \\
\hline
\end{tabular}

Indicator Description:

$$
\begin{aligned}
& A=\text { Planning } \\
& B=\text { Organizing } \\
& C=\text { Leadership } \\
& D=\text { Control } \\
& E=\text { Staffing }
\end{aligned}
$$

Table 4 shows the acquisition of management scores based on assessment indicators. It can be seen that the most prominent indicator in the management of the National Team is Personnel (E) with a total score of 132.43.

Furthermore, the planning indicator (A) with a score of 131.73. Control Indicator (D) obtained a score of 130.08. While the Organizing (B) and Leadership (C) and foreign indicators each score 128.57 and 128.22. The overall score of the indicators that get the highest score in the management of the Pencak Silat National Team is the staffing indicator. While the indicator that gets the lowest score is Leadership. The dependent variable in this study was the achievement of the Indonesian Pencak Silat National Team. This achievement data is reviewed from the results of the 2017 Sea Games 2017 and the 2018 Asian Games that have been completed which can be seen in the following table:

Table 4. Indonesian National Pencak Silat Team Achievement Data

\begin{tabular}{cccc}
\hline \multirow{2}{*}{ Event } & \multicolumn{3}{c}{ Medal } \\
\cline { 2 - 4 } & Gold & Silver & Bronze \\
\hline Sea Games 2017 & 2 & 4 & 9 \\
2018 Asian Games & 14 & 0 & 1 \\
\hline
\end{tabular}

Table 5 shows that the 2018 Asian Games event was the success of the Indonesian Pencak Silat national team which almost bought up all the gold medals competed, Indonesia only failed to win 2 gold from the 16 golds contested. Inversely proportional in the Sea Games 2017 Indonesian Pencak Silat national team won only 2 gold, 4 silver and 9 bronze.

Next in table 6 will show a statistical prerequisite test that is test data normality using the Liliefors test. The results can be seen in the following table: 
Table 5. Data Normality Test

\begin{tabular}{lccc}
\hline & $\begin{array}{c}\text { Shapiro- } \\
\text { Wilk }\end{array}$ & Sig. & Information \\
\hline Management & 0.905 & 0.081 & Normal \\
Achievement & 0.897 & 0.067 & Normal \\
\hline
\end{tabular}

Table 6 shows the management data of Indonesian Pencak Silat national team with Shapiro-Wilk value $=0.905$ and Sig. $=0.081>0.05$ then the data is distributed normally. Indonesian National Pencak Silat national team data with ShapiroWilk value $=0.897$ and Sig. $=0.067>0.05$ can be interpreted as normally distributed data. Based on these results all data are declared normal. After conducting and obtaining the data normality test results, the next statistical test step is the hypothesis test.

In the research hypothesis testing is done through correlation and regression tests (person correlation and linear regression). Here are the results of testing the hypothesis can be seen in tables 7 and 8

Table 6. Correlation Test Results

\begin{tabular}{ccc}
\hline R & Sig. & Information \\
\hline 0.795 & 0,000 & Significant Relationship \\
\hline
\end{tabular}

Table 7. Regression Test Results

\begin{tabular}{lc}
\hline & R Square \\
\hline 0.795 & .663 \\
\hline
\end{tabular}

Seen that result in Table 7 was obtained the correlation coefficient $(r)=$ 0, 795 and sig on P_VALUE 0,000, it proves that there is a positive and significant relationship between management and the achievement of the team Pencak Silat Indonesia. This proves that the increase in scores on the variables of management will be followed by a rise in performance variables, and vice versa, meaning that if the management at every team better, it will be followed by achievements performance tend to be good. In addition, the additional analysis set forth in table 8 examines how big of the contribution of the management variable to the achievement variable, as evidenced by the coefficient of determination ( $R$ square $=0.795$ ) obtained for 0,663 , this can be interpreted that the management contributed $66,3 \%$ in determining the success of the Indonesian Pencak Silat national team achievements.

The results of testing the hypothesis indicate a high correlation value between management and the achievements of the Indonesian Pencak Silat National Team. In addition, further tests conducted using regression tests indicate the amount of management management's contribution to the national team's performance is fairly high. With these results provide further evidence on the relationship between the management team of the achievements of the team itself. Good management is directly proportional to the good achievements. However, these results are the evidence of overall management correlation. To provide a deeper explanation, researchers also 
show the correlation test of each management indicator for achievement. These results can be seen in Tables 9 and 10:

Table 8. Correlation Test Management Indicators To Achievement

\begin{tabular}{lccl}
\hline \multicolumn{1}{c}{ Indicator } & $\mathrm{R}$ & Sig. & Information \\
\hline Planning & 0.826 & 0,000 & Significant Relationship \\
Organizing & .804 & 0,000 & Significant Relationship \\
Leadership & 0.745 & 0,000 & Significant Relationship \\
Control & 0.790 & 0,000 & Significant Relationship \\
Staffing & 0.844 & 0,000 & Significant Relationship \\
\hline
\end{tabular}

Table 9. Regression Test of Management Indicators for Achievement

\begin{tabular}{|c|c|c|}
\hline Indicator & $\mathrm{R}$ & R Square \\
\hline Planning & 0.826 & .682 \\
\hline Organizing & .804 & 0.646 \\
\hline Leadership & 0.790 & 0.624 \\
\hline Control & 0.745 & 0.555 \\
\hline Staffing & 0.844 & 0.712 \\
\hline
\end{tabular}

Tables 9 and 10 show the correlation and regression values of each management indicator on the achievements of the Indonesian Pencak Silat National Team.

a. In the Planning indicator, the value of $r=0.826$ and sig $=0.000<0.05$, the relationship is significant, or it can be stated that there is a positive and significant relationship between the management of Planning on the achievement of the National Team. With the value of r-square $=0.682$ means the relationship between management and planning of the achievements of the national team at $68.2 \%$.

b. Organizational Indicators get $r=0,804$ and $\operatorname{sig}=0,000<0.05$, then a significant relationship, or it can be stated that there is a positive and significant relationship between Organizing management and national team achievement. With the value of rs quare $=0.646$ means the relationship between the management organization of the achievements of the national team by $64.6 \%$.

c. Leadership Indicators obtained a value of $r=0,790$ and $\operatorname{sig}=0,000<0.05$ then a significant relationship, or it can be stated that there is a positive and significant relationship between leadership management on national team achievement. With the value of $r$-square $=0,624$ defined the relationship between management and leadership to the team achievement of $62.4 \%$.

d. Control Indicators get the value of $r=0,745$ and sig $=0,000<0.05$, the relationship is significant, or it can be stated that there is a positive and significant relationship between Control management on national team achievement. With the value of r-square $=0,555$ defined the relationship between the management control of the achievements of the national team at $55.5 \%$.

e. Staffing Indicators get a value of $r=0,844$ and $\operatorname{sig}=0,000<0.05$ then a significant relationship, or it can be stated that there is a positive and signifi- 
cant relationship between staffing management on national team achievement. With the value of r-square $=0,712$ defined the relationship between the management staff of the achievements the national team at $71.2 \%$.

The results of the national team management correlation test based on each indicator to the achievements above show all indicators have a positive and significant relationship to the performance of the Indonesian Pencak Silat National Team. In addition, further tests using the regression test showed a significant contribution between each management indicator to the national team's achievements. Of all the management indicators, the staff indicator shows the highest value compared to the other indicators.

The results of the research that have been done provide an overview in the form of research data through the questionnaire management of the Pencak Silat national team Based on data from research results that have been through the processing and analysis of data shows that on average the overall score obtained 173.13, which falls into either category. Based on management indicators shows that the most prominent in team management is staffing with a total score of 132.43. Furthermore, planning indicators with a score of 131.73. The Control Indicator gained a score of 130.08. While the organizing and leadership indicators each scored 128.57 and 128.22. Based on the questionnaire that has been distributed to the Indonesian Pencak Silat team, it shows that the indicator that gets the highest score is the staffing indicator. This was corroborated by research [14] that says " original insights into the educational needs of sports science and management staff, which can inform practitioners who face increasing demands to work with such personnel, and raise sports organizations' awareness of Reviews their duty of care to employees and the factors that need to be managed" the intent of the statement is the need for management staff educated sports science, which can provide information practitioners are facing increasing demands to work with team members that, and raise awareness of sports organizations about their care assignments to fellow teams and the factors that need to be considered and managed .

This illustrates that most of the teams have done quite well in terms of staffing. In other indicators, the results of the study show that the indicator that gets the lowest score is the leadership indicator. Leadership management functions to direct, influence, motivate, mentoring, conflict resolution and as a role model for team members, observing and evaluating the management process so that the planning made can achieve the expected results [15] [16]. Based on the results of an interview with one of the athletes, the manager sets a target and is delivered to his athletes, motivates each game, and the manager's communication with the athlete is very good. In connection with these results indicate that staffing management has been done well, while the leadership management of the Indonesian national team Pencak Silat is still lacking compared to other management indicators. Both of these results illustrate that the best composition that has been formed will not run well if it has not been supported by good leadership management. So that it can lead to achievement of goals that are not optimal. Every indicator in management is very important to be considered, especially in the management of a sports team [17] [18] [19].

The achievements of the Indonesian Pencak Silat national team at the 2017 Sea Games and the 2018 Asian Games in management is already well underway in ac- 
cordance with the duties of his respective, excellent team of coaches, athletes and teams support incorporated in the Indonesian National Pencak Silat team. The results achieved in the 2017 Sea Games are more on the non-technical factors experienced by the Indonesian team such as cheating and decisions that are detrimental to the Indonesian team. Inversely proportional in the 2018 Asian Games Indonesia achieved very good success. Plus the appointment of Indonesia as a host that is fully supported by family, relatives and all Indonesian people who witnessed directly or through electronic media adds to the spirit of competing athletes to offer the best for the State of Indonesia. Regarding management in sports [20] states: Management applied sport contributes to achieving full functionality of sports structures, the large masses of people, a plurality of means and skills, objectives and intentions. Management in sport helps to control possession and sports activities that can generate process efficiencies across the organization on. The application of management in sports contributes in various ways, including the achievement of team goals [21]. Management in sports helps control processes that can have an impact on efficiency in all sports teams [22] [23]. The conclusion obtained in this research is the management of the Indonesian National Pencak Silat team in the good category.

Then the results showed that there was a significant and positive relationship between management and the achievements of the Indonesian national team. Thus it can be interpreted that the better the management, the better the achievement. Management is proven to be able to make a positive contribution to team performance by $66.3 \%$. The results of this study are in accordance with the statement of [23] which states that "With proper management achievements will be achieved easily. All the elements that exist in supporting the sports achievements must be mutually supportive and sustainable. "Achievement is supported by good management and also supported by all elements that are mutually sustainable. Sports team achievement is the achievement of the goals of a team that competes in a particular competition. The team needs a good management to be able to achieve every goal set. In accordance with the statement of [26] "Every individual belongs to formal organizations, through a democratic and cooperative approach to management, the individual can help in what has proved to be successful in the past". Democratic approach and cooperative towards management, individuals can help the success. In addition to management can help success, management is also a facility to achieve goals. [26] say that "A knowledge of management facilitates the achievement of such aims." Knowledge about management becomes a facility for achievement. In addition to the importance of management for achievement stated [23] which states that "To improve the absolute achievement of an organization has a main goal based on existing management functions". Each team must know and understand management functions and carry them out according to the stages that should be. [23] added that "Sports achievement is influenced by many factors, one of which is in sports management by sports organizations. The management functions include (planning, organizing, leadership, controlling, staffing). With the correct process and implementation in accordance with what is desired is an achievement, then all aspects relating to sports achievements must be fixed. "Management is one of the factors of a team or sports organization to achieve achievement [24]. Therefore, every team and or sports organization must pay more attention and carry out better management for maximum results. 


\section{Conclusion}

In accordance with the results of data processing and analysis, it can be concluded that the management of the Indonesian Pencak Silat national team at the Seagames 2017 and Asian Games 2018 is included in the good category. Then there is a significant and positive relationship between management and achievement. It can be seen in this study that the management contribution made to the Indonesian Pencak Silat national team was $66.3 \%$.

\section{References}

[1] Flynn S, College GH, Jellum L, College GH, College GH, Moser A, et al. Concepts of Fitness and Wellness, 2nd Edition 2018.

[2] Belski R, Forsyth A, Mantzioris E. Nutrition for Sport, Exercise and Performance 2019.

[3] Bailey R, Neuroscience E. Sport in Society Sport , physical activity and educational achievement - towards an explanatory model 2017.

[4] Kemenpora. UU Sistem Keolahragaan Nasional 2005.

[5] Mallett CJ, Hanrahan SJ. Elite athletes: why does the 'fire' burn so brightly? Psychol Sport Exerc 2004;5:183-200.

[6] Shahidian S, Sampaio J, Leite N. The Importance of Sports Performance Factors and Training Contents From the Perspective of Futsal Coaches 2013;38:151-60.

[7] Adling RB. Importance of sports psychology in physical education and sports 2017;2:215-8.

[8] Bloom GA, Falcão WR, Caron JG. Coaching high performance athletes : Implications for coach training 2016.

[9] Griffiths K. Personal coaching: a model for effective 2005;1:55-65.

[10] Joo B-K (Brian). Executive Coaching: A Conceptual Framework From an Integrative Review of Practice and Research. Hum Resour Dev Rev 2005;4:462-88.

[11] Becker AJ. It' s Not What They Do, It's How They Do It: Athlete Experiences of Great Coaching 2009;4:93-119.

[12] Pal DK. Management Concepts and Organizational Behaviour 2011:1-720.

[13] Gunnigle P, Mcdonnell A. Performance management 2008.

[14] Arnold R, Collington S, Manley H, Rees S, Soanes J, Williams M, et al. “ The Team Behind the Team ": Exploring the Organizational Stressor Experiences of Sport Science and Management Staff in Elite Sport. J Appl Sport Psychol 2017;0:1-20.

[15] Michael A. Mentoring and Coaching 2008:1-19.

[16] Kolzow DR. Leading from within: Building Organizational Leadership Capacity Authored by: Table of Contents. 2014.

[17] Jones NMP, Mellalieu SD, James N. Team performance indicators as a function of winning and losing in rugby union. Int J Perform Anal Sport 2004;4:61-71.

[18] Gabcanova I. Human Resources Key Performance Indicators. J Compet 2012;4:117-28.

[19] Serra P. Sociology of Sport. 2015.

[20] Cucui GG, Cucui IA. Analysisis of the management system football clubs (junior) 2016;9.

[21] Kieran K. The application of goal setting in sport 2017.

[22] Ratten V. The impact of sports on team performance management. Team Perform Manag An Int J 2009;15:97-9.

[23] Kasale LL, Winand M, Robinson L. Performance management of National Sports Organisations: a holistic theoretical model. Sport Bus Manag An Int J 2018;8:469-91.

[24] Boakye EO. The impact of teamwork on employee performance 2015. 